The Girls Work Method: What is the Role of Empowerment in Building Girls' Agency?

\title{
The Girls Work Method: What is the Role of Empowerment in Building
}

\section{Girls’ Agency?}

Cynthia Boomkens, Judith W. Metz, René M.J.D. Schalk and Tine M.R.F. Van

Regenmortel

Amsterdam University of Applied Sciences; Tilburg University

Author Note

Cynthia Boomkens, Centre for Applied Research in Social Work and Law, Amsterdam University for applied Sciences, Amsterdam, The Netherlands, Tilburg School of Social and Behavioral Sciences, Tranzo, Tilburg University, Tilburg, Netherlands; Judith Metz, Centre for Applied Research in Social Work and Law, Amsterdam University for applied Sciences; René Schalk, Tilburg School of Social and Behavioral Sciences, Tranzo, Tilburg University, Tilburg, Netherlands, Economic and Management Sciences, North-West University, Potchefstroom, South Africa; Tine van Regenmortel, Faculty of Social Sciences - HIVA, University of Leuven, Leuven, Belgium, Tilburg School of Social and Behavioral Sciences, Tranzo, Tilburg University, Tilburg, Netherlands.

Correspondence concerning this article should be addressed to Cynthia Boomkens, Centre for Applied Research in Social Work and Law, Amsterdam University for applied Sciences, 1091GH, Amsterdam, The Netherlands.

E-mail: c.boomkens@hva.nl 
The Girls Work Method: What is the Role of Empowerment in Building Girls' Agency?

\title{
The Girls Work Method: What is the Role of Empowerment in Building
}

\section{Girls’ Agency?}

\begin{abstract}
Girls Work, as one of the methods used by professional youth work, focuses on helping vulnerable girls to shape their own lives (a capacity also referred to as 'agency'). In this study, it is hypothesized that the methodical principles (i.e., the guiding principles of the methodical actions of the youth worker) contribute to the empowerment process of girls, which in turn leads to the development of girls' agency. Serial mediation was used to test this hypothesis. Results indicate that all of the methodical principles, with the exception of the use of context, are important to helping girls develop agency. Four of the methodical principles contribute to both empowerment and agency, while the other methodical principles contribute to agency only through empowerment. This paper also addresses the importance of focusing on the empowerment of girls, as empowerment is positively linked with agency. All of the components of individual empowerment are important when helping girls develop their agency.
\end{abstract}

Keywords: youth, girls work, agency, empowerment, practice/theory/methods

\section{Introduction}

In the past decade, youth work in Europe have become more oriented on personal development of young people and policy on youth work has move towards more evidence-based youth work (Dunne, Ulicna, Murphy \& Golubeva, 2014). Because of this, older models of youth work are being questioned and new theoretical models emerge. This is also the case for Girls Work in the Netherlands, as one of the methods of youth work which focus on girls between 10 and 23 years. Youth workers who work with girls, indicate that they need a (new) model of Girls Work, which 
The Girls Work Method: What is the Role of Empowerment in Building Girls’ Agency?

is substantiated with theory and empirical data. In previous research, we therefore examined the goal of Girls Work, what youth workers do in contact with girls and how we can theoretically substantiate this (Boomkens, Rauwerdink-Nijland, Van der Grient, Van Trijp \& Metz, 2018). Based on that, we described the new model for Girls Work in which we hypothesized that the actions of the youth workers (methodical principles) contribute to the aim of Girls Work (shaping their own lives, also understood as agency). This contribution is mediated through empowerment (see also Figure 1). With the present study, we want to empirical test this hypothesis. First, we further operationalize the model of Girls Work.

Fig. 1 Models of indirect effects.

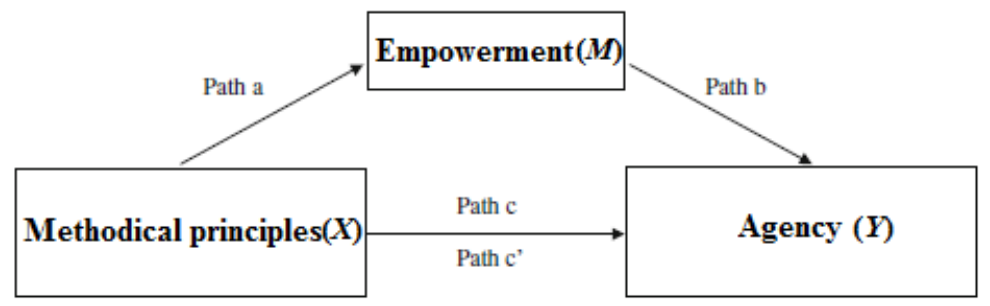

Girls Work in the Netherlands focus on supporting girls between 10 and 23 years old with their identity development, so that they are better able to shape their own lives on their way to adulthood (Batsleer, 2013; Gemmeke et al., 2011; Van der Zande, 1991). Most girls succeed with this themselves or with support of their social contexts. However, there is a (growing) group of girls who need the support from professionals, because they face one or more forms of vulnerability, e.g. they live in a stressful home situation or in poverty, are confronted with abuse, are being bullied or discriminated, have problems at school, have a disability (cognitive, mental, social or physical) (Abdallah, 2017). Girls Work in the Netherlands is carried out by paid youth 
The Girls Work Method: What is the Role of Empowerment in Building Girls’ Agency?

workers who have completed a formal education (Metz, 2016) and is positioned in the leisure time of girls (Dunne et al., 2014; Haidinger, Kasper, Knecht, Kuchler \& Atzmüller, 2016). The reason for having gender-specific youth work is the underrepresentation of girls in regular youth work activities (approximately 10-30\% of the youth in these activities are girls) (Gemmeke et al., 2011). This is due to the dominance of boys through their more extravert behaviour, because activities do not always appeal to girls, and because parents and caregivers do not always allow girls to participate because of safety concerns (e.g. because the activities are offered in an unfamiliar neighbourhood or because boys are present) (De Boer \& Metz, 2015; Van Drent \& Te Poel, 1991). Girls Work is an open approach method, which involves professional interventions with a goal-oriented, process-based, moral and dialogical character (Metz, 2016). There are two types of Girls Work: the group approach and the individual approach. When working with a group, the group usually consists of a fairly fixed group of girls (usually around 8 to 12 girls) who meet each other for a certain amount of time. In addition to group activities, youth workers can also offer individual support. The choice for one or both approaches depends on the individual girl's needs, the context, the organization, and the assignment of the municipality.

The aim of Girls Work is to guide and support girls in their identity development, so that they, as adults, can shape their lives. In previous research on Girls Work, we theoretically understood this aim as agency (Boomkens \& Metz,, 2015). Agency has many operationalisations, such as people's ability to act (Campbell, 2009; Charrad, 2010; Gillepsie, 2012; Han, Nicholas, Aimer, \& Gray, 2015; Philips, 2013), to act on behalf what matters to people (Alkire, 2005; Dryduk, 2013) or to intentionally doing things and to make purposeful choices about their lives (Maynard \& Stuart, 2018; Meesters, 2018; Paternoster \& Pogarsky, 2009; Samman \& Santos, 2009). Others also include the power of individuals to influence their own life course (Elder, 1998; 
The Girls Work Method: What is the Role of Empowerment in Building Girls’ Agency?

Hutchinson, 2005; Pollack, 2008; Stuart, 2014; Schwartz, Côté \& Arnett, 2005). However, for theoretically understanding the aim of Girls Work we use the operationalization of Bandura (2006), because it refers to the human capacity to consciously influence its own functioning and living conditions. Within Girls Work, youth workers are trying to support girls, therefore girls know better what they want in their lives (they act more consciously) and helps them to actually achieve it (to influence their own lives). Also, Bandura highlights four core properties of agency (also described - but not named - by other researchers), that helps youth workers to better translate this theoretical concept to their practice. The first property is intentionality, and refers to the freedom of doing what one wants and making purposeful choices (Borovoy \& Ghodsee, 2012; Samman \& Santos, 2009). The property of forethought involves setting realistic goals and anticipating likely outcomes (Bandura, 2006). Borovoy and Ghodsee (2012) emphasize that women, more than men, seek to make comparative assessments between what they want and what the consequences of their actions could be. Self-reactiveness is the property where intentions are converted into actions (Bandura, 2006). Most researchers emphasize this as an important part of agency (Charrad, 2010; McMunn, Bartley \& Kuh, 2006; Pollack, 2008; Tang \& Anderson, 1999). Finally, self-reflection refers to how people reflect on their thoughts and actions (Bandura, 2006). When people reflect on their thoughts and actions, they can develop a clear understanding of their personal efficacy and of the world around them (Tang \& Anderson, 1999). The theory of agency suggests that in order to shape one's own life as adults, girls need to develop all four properties of agency.

The development of agency is influenced by the process of empowerment (Alkire, 2005; Boomkens et al., 2018a; Maynard \& Stuart, 2017). Empowerment is a highly debated concept and many different operationalization's occur (Baumans, 2012; Maynard \& Stuart, 2017). 
The Girls Work Method: What is the Role of Empowerment in Building Girls’ Agency?

However, it has often been defined as a mechanism by which people, groups, and communities gain control over their affairs (Rappaport, 1987). Translated to Girls Work: when youth workers focus on girls' empowerment, they focus on strengthening girls to make them more capable to shape their own lives. Much of the research on empowerment focus on psychological empowerment (Christens, Speer \& Peterson, 2011), which refers to empowerment at the individual level (Zimmerman, 1995). This emphasis on the individual does not mean that other contextual factors are overlooked, but the individual level influence and is being influenced by empowerment at the organizational and community levels (Zimmerman, 1995). Because Girls Work focus merely on the individual as well (and take into account how girls are being influenced and influence their social contexts), we choose the use the process of psychological empowerment in our study. Psychological empowerment consist of three components: intrapersonal, interactional, and behavioural components. The intrapersonal component refers to people's own perception of personal control (Zimmerman, 1995; Delahaij, 2004; Baumans, 2011). This consist of self-efficacy beliefs, motivation and the perception of personal control, or the 'locus of control' (Delahaij, 2004). The interactional component is more about the actual ability of an individual to exercise control. Central within the interactional component is learning to understand the context, to develop an awareness of possibilities to achieve goals (Zimmerman, 1995), and to acquire the necessary knowledge and skills needed to achieve goals (Delahaij 2004). Last, the behavioural component refers to the actual action by which people gain more control over their own lives (Zimmerman, 1995). Participation is the core principle here. Through participation people (a) can directly influence the environment, (b) learn new skills, (c) increase the social context and (d) strengthen the sense of personal control. 
The Girls Work Method: What is the Role of Empowerment in Building Girls' Agency?

The psychological level of empowerment may be able to explain the processes by which girls acquire agency (Boomkens \& Metz, 2015). This relation between agency and empowerment has been described theoretically by other researchers, although they do not always explicitly use the concepts of agency and empowerment. Donald, Koolwal, Annan, Falb and Goldstein (2016) have described the link between agency and personal control (the first component of empowerment). They state that in order to become an agent, individuals need to perceive an own sense of control. They also state that people's agency is influenced by the resources available to the individual and how the individual interacts with these resources (known as the interactional component in empowerment theory). Several researchers state that to achieve agency, participation (part of the last component of empowerment) is an important step (Berger \& Neuhaus, 1977; Christens et al., 2011; Lyons, Smuts \& Stephens, 2001; Prestby, Wandersman, Florin, Rich \& Chavis, 1990; Rich, Edelstein, Hallman \& Wandersman, 1995; Zimmerman, Israel, Schulz \& Checkoway, 1992). Although the relation between agency and empowerment has been described frequently, these associations have not been tested for significance as an indirect effect. Also, the amount of research on the development of agency within Girls Work remain limited.

In our previous research on Girls Work in the Netherlands, we identified nine so-called methodical principles to describe the methodical actions of the youth worker in interaction with girls (De Boer \& Metz, 2014; Metz, 2016). The methodical principles were identified though Programme Evaluation, which focus on the construction of a valid description of a social program, in ways that are in line with scientific standards and applicable in practice (Rossi, Lipsey \& Freeman, 2004). To determine what the action of youth workers in contact with girls are, we conducted focus groups and individual interviews with youth workers who work with girls (De Boer \& Metz, 2014; Metz, 2016). The results were presented to these and other youth workers for 
The Girls Work Method: What is the Role of Empowerment in Building Girls’ Agency?

validation, which resulted in the use of nine methodical principles. These principles - some of which are specifically for working with girls or have a gender-specific interpretation - can be applied separately or in conjunction according to the situation, goals, persons and resources available for the given working methods, target groups, goals and contexts (Metz, 2016). The nine methodical principles are: Safety (girls need to feel safe to be or to explore who they are in the Girls Work activity), Meaningful relationship (the relationship between the girl(s) and the youth worker should be important enough to make a difference in their lives), Acquaintance (the youth worker really knows a girl/the girls), Take into account the needs of girls (the youth worker are meeting the needs of every girl), Positive motivation (focusing on the positive actions/behaviour by girls instead of on punishment for bad behaviour), Boundaries (to make girls aware of generally accepted behaviour and how their behaviour affects others), Expanding lifeworld (exposing girls to new experiences and social opportunities), Talk (talking refers to the many and easy ways that girls talk and the role that talking plays in their development) and Use of social context (the youth worker draws on people, networks, organizations and facilities that can contribute to the girls' development). The identification of the nine methodical principles is based on practice knowledge of youth workers. Much remains unknown about the contribution of these principles to the aim of Girls Work.

It is hypothesized that with these nine methodical principles, the youth worker facilitates a process through which girls can develop agency: the ability of individuals to shape their own life, in relation to their own values and in alignment with their own social context (see also Boomkens \& Metz, 2015).

The present study addressed these research needs by examining the relationships between the methodical principles and girls' agency. This study considers a main mediation model in which 
The Girls Work Method: What is the Role of Empowerment in Building Girls’ Agency?

we hypothesize that the methodical principles contribute, through the empowerment process, to the agency of vulnerable girls (see Figure 1).

\section{Methods}

\section{Design}

We used a cross-sectional design to explore whether girls' agency is influenced by the methodical principles, and whether this influence is mediated by empowerment. The research was performed in close collaboration with eight youth work organizations in urban and rural areas in the Netherlands. They opened their practice for data collection and arranged at least two youth workers to participate in a masterclass, and two girls to participate in the girls group. The masterclass and the girls group consist of experienced youth workers working with girls and girls who have participated in Girls Work for at least two years. Both groups helped to develop the questionnaire and protocol for data collection. This collaboration ensured that the research methods were appropriate to the Girls Work practice (Metz, 2016).

We consulted the masterclass to examine whether the items met the criteria of agency, empowerment and the methodical principles, which resulted in some changes to the scale. We consulted the girls group once to present the scale to check the following conditions: comprehension of the questions, attractiveness and duration. We also tested the scale twice with four different girls of the girls group, which led to minor adjustments such as the deletion or reformulation of some questions. Girls who participated in the girls group were treated to a goody bag and a group dinner in return for their participation.

\section{Sample and procedure}


The Girls Work Method: What is the Role of Empowerment in Building Girls' Agency?

The eight youth work organizations selected approximately 80 Girls Work activities in urban and rural areas in the Netherlands to participate in this study, based on the dispersion of their target group (e.g. girls of different ages, cultural backgrounds, education) and their Girls Work activities (e.g. different types of Girls Work activities, new and older activities). Data collection was cancelled at 28 activities for a variety of reasons: e.g. sickness of the youth worker or participant, problems with public transportation due to weather conditions, a fight between the girls, and too much pressure on a youth worker involved in multiple selected activities. This led to a total of 52 Girls Work activities that were visited between November 2016 and February 2017. Girls aged between 10 and 23 were asked to fill out an online questionnaire during regular Girls Work activities. Only when no internet was available, girls were offered the opportunity to fill out a paper version of the questionnaire. The youth worker was absent during the survey to reduce response bias. Participation in the study was voluntary and anonymous and respondents were offered a certificate and a wristband with the text 'girls run the world' after finishing the questionnaire.

All girls who were present on the day of data collection were asked to participate in the research. Of the 632 to $676^{1}$ girls who participated in these activities, 435 girls completed the questionnaire (response rate of approximately 65\%). In 39 cases, the online questionnaire failed to yield any answers because the participant did not press 'send' or because of an instable Wi-Fi connection. Finally, we excluded 3 respondents who were younger than 10 years old. This led to the final sample of 393 girls (response rate of approximately 58\%). The mean age of the sample

\footnotetext{
${ }^{1}$ Youth workers were asked how many girls participate in their Girls Work activities. Most youth workers estimated the number of girls, as for most activities the number is uncertain due to incomplete registrations and weekly fluctuating attendance numbers.
} 
The Girls Work Method: What is the Role of Empowerment in Building Girls’ Agency?

was 13.68 years old $(S D=3.27)$. Although $92 \%$ was born in the Netherlands, $74 \%$ had a mixed cultural background. $72.5 \%$ of the girls lived with both parents and $20.1 \%$ lived with one parent. Other participants lived: alone $(1.3 \%)$, 'I have no permanent residence' $(1.3 \%)$, with another relative $(1.0 \%)$, in sheltered living $(1.0 \%)$, with a partner $(0.8 \%)$ or with friends $(0.5 \%)$. From the girls attending secondary school, 72\% followed vocational education and (Dutch: VMBO) 28\% higher education (Dutch: HAVO / VWO). Most girls in our sample participated in Girls Work once a week (57.5\%). 20.9\% participated in Girls Work more than once a week and $21.1 \%$ did so less than once a week.

The data collection was conducted by the researcher and by students of social work education of different applied universities. The students were trained by the researcher before collecting the data. This training included attention for the attitude towards the girls and youth worker, rules for data collection (e.g. girls younger than 10 or older than 23 were not eligible to participate, the youth worker had to be out of the room), instructions regarding the questionnaire (questions and digital environment) and confidentiality. Students received credits for their assignment (e.g. thesis or portfolio).

\section{Measures}

For this study, we used three self-constructed scales to measure agency, empowerment and the methodical principles of the Girls Work method. Since we wanted to measure the concept of agency as defined by Bandura (2006), we developed the scale ourselves (see also Boomkens, Metz, Van Regenmortel \& Schalk, 2018). We operationalized Bandura's agency in terms of the four properties: intentionality, forethought, self-reactiveness and self-reflection. We also constructed a scale to measure empowerment (see Appendix), because available scales were 
The Girls Work Method: What is the Role of Empowerment in Building Girls' Agency?

either too long (e.g. Akey, Marquis, \& Ross, 2000), did not measure all three components of psychological empowerment (e.g. Teeuw, Schwarzer \& Jerusalem, 1994), or items were too generally operationalized (e.g. Israel, Checkoway, Schulz \& Zimmerman, 1994).

Items were measured on a five-point Likert scale from 1 representing 'strongly disagree' to 5 representing 'strongly agree'. We conducted an exploratory factor analysis (principal component analysis and direct oblimin rotation) of the responses of the 393 respondents to determine the validity of the two scales. We examined all the factors evident when the eigenvalues are $>1$. Four of the factors were directly related with the four properties of agency and three of the factors were directly related with the three components of empowerment (see Table 1). To measure agency as a whole, we used 13 items $(\alpha=.833)$ and to measure empowerment as a whole, we used 17 items $(\alpha=.826)$.

Table 1. Construction of the scale and subscales of agency and empowerment

\begin{tabular}{lllll}
\hline & Variance & $\alpha$ & Number of items & Minimum - maximum \\
\hline Agency: total & - & & & $1-5$ \\
Intentionality & $25.2 \%$ & .833 & 13 & $1-5$ \\
Forethought & $11.1 \%$ & .813 & 4 & $1-5$ \\
Self-reactiveness & $10.5 \%$ & .748 & 4 & $1-5$ \\
Self-reflection & $7.5 \%$ & .750 & 3 & $1-5$ \\
Empowerment: total - & .826 & 17 & $1-5$ \\
Personal control & $33.5 \%$ & .766 & 7 & $1-5$ \\
Critical awareness $10.8 \%$ & .799 & 6 & $1-5$ \\
Participation & $7.3 \%$ & .744 & 4 & $1-5$ \\
\hline
\end{tabular}

To measure the methodical principles of the Girls Work method, we developed a scale ourselves (see Appendix). This, because the principles for Girls Work can only be identified and substantiated through practice knowledge (Metz, 2016), therefore no scales are available to measure these methodical principles. We first operationalized the nine methodical principles in 
The Girls Work Method: What is the Role of Empowerment in Building Girls' Agency?

a way that girls could indicate whether they experienced the presence of each methodical principle. Next, we consulted the masterclass to check whether the items were still in line with the methodical principles. Due to an error in the software, we could not measure the principle 'use of social context' correctly. Therefore we decided to leave this principle out of the analysis.

The final scale consisted of 27 items which were measured on a two-point scale or on a four-point scale. We made Z-scores for all the items measuring the methodical principles and conducted a confirmatory factor analysis (principal component analysis and direct oblimin rotation), where five of the methodical principles were divided into five different factors. The methodical principle of 'positive motivation' partially overlaps with 'meaningful relationship', especially the items that involve the actions of the youth worker. As youth workers propose to differentiate between these methodical principles (De Boer \& Metz, 2014), we chose to leave these items with 'positive motivation'. The methodical principles of 'talking individual', 'talking in groups' and 'expanding lifeworld' overlap. We chose to measure these principles individually, based on one item. Cronbach's alpha was .93 for all the methodical principles together (see Table 2).

Table 2. Construction of the scale and subscales

\begin{tabular}{lll}
\hline & $\alpha$ & Number of items \\
\hline Methodical principles: total & .93 & 29 \\
Safety & - & 1 \\
Meaningful relationship & .84 & 4 \\
Acquaintance (Knowing) & .89 & 4 \\
Take into account the needs of girls & .71 & 2 \\
Positive motivation & .75 & 6 \\
Boundaries & .89 & 9 \\
Talk individual & - & 1 \\
Talk in groups & - & 1 \\
Expanding lifeworld & - & 1 \\
\hline
\end{tabular}


The Girls Work Method: What is the Role of Empowerment in Building Girls' Agency?

\section{Analysis}

The analyses were conducted using SPSS PASW Statistics 18 for descriptive analysis and using Hayes (2013) PROCESS macro for IBM SPSS (Preacher \& Hayes, 2008) for mediation analyses to empirically examine the impact of each predictor (independent and mediator variable) in turn, rather than the simultaneous impact of mediators in a parallel mediation (Preacher \& Hayes, 2008). To test the indirect effects of the methodical principles and empowerment to agency, we used a bootstrapping approach with 5000 resamples. Bootstrapping is a non-parametric method used to estimate indirect effects and it overcomes many of the problems that accompany other mediation approaches, such as the requirement of normally distributed data and power problems (Preacher \& Hayes, 2008). With a bootstrapping approach, significant indirect effects are indicated when the 95\% bias-corrected confidence interval for $\mathrm{a} x \mathrm{~b}$ does not overlap with zero.

Since age is a strong predictor of agency (Boomkens et al., 2018b), we controlled the mediation analyses for age. We also controlled the mediation for duration of participation in Girls Work.

\section{Ethical considerations}

This study is carried out in line with the Netherlands Code of Conduct for Scientific Practice (VSNU, 2014). For example, the managers of all the organizations who participated in this study had approved the data collection. The girls and their parents (especially when girls were younger than 16 years old) were informed about the study by the youth worker by means of a letter. Also, posters were hung in that spaces or hallways of all the participating activities, to make sure that all the parents and girls were informed about the study. All material were provided to the youth 
The Girls Work Method: What is the Role of Empowerment in Building Girls’ Agency?

workers by the researchers. Participation in the study was voluntary and all the girls and their parents were given the opportunity to withdraw from the study, prior to the data collection, on the day itself or even during the study. We ensured anonymity of all the girls and the Girls Work activities which they attended, since no questions were asked from which the origin could be guided. Also, all students who supported in the data collection had to sign a confidentially form before they could visit the Girls Work activities. The researchers declare that they have no conflict of interest.

\section{Results}

\section{Preliminary analyses}

Correlation analyses between the three concepts showed that empowerment and the methodical principles were significantly and positively correlated to agency of girls $(r=.5724, p=<.001$; $r=.472, p=<.001$ respectively). The concepts were tested for multicollinearity using the variance inflation factor (VIF). The VIF indicates whether the independent variables have a strong linear relationship with the dependent variable (Myers, 1990 in Field, 2009). Because all the VIF values were below 10.0 (1.429), multicollinearity was not an issue in this study.

\section{Agency and empowerment}

Table 3 provides descriptive statistics on agency and empowerment. The girls assigned a score for the level of agency with a mean of $3.85(S D=0.54)$, ranging between 2.14 (minimum) and 5.00 (maximum). For empowerment the girls assigned a score with a mean of $3.79(S D=0.54)$, ranging between 1.59 (minimum) and 5.00 (maximum). 
The Girls Work Method: What is the Role of Empowerment in Building Girls’ Agency?

Table 3. Descriptive statistics for the full sample and separately by age.

\begin{tabular}{ll}
\hline & $M(S D)$ \\
\hline Agency: total & $3.85(0.53)$ \\
Intentionality & $4.00(0.79)$ \\
Forethought & $3.85(0.69)$ \\
Self-reactiveness & $3.96(0.71)$ \\
Self-reflection & $3.54(0.87)$ \\
Empowerment: total & $3.79(0.54)$ \\
Personal control & $3.93(0.61)$ \\
Critical awareness & $3.77(0.67)$ \\
Participation & $3.58(0.78)$ \\
\hline
\end{tabular}

\section{Mediation Model}

To examine whether the methodical principles positively effects girls' agency, and whether this effect is mediated through empowerment, we used a mediation analysis. We tested three possible models of mediation. The first model tested the mediation of the three concepts as a whole (the eight methodical principles combined, empowerment as a whole and agency as a whole). Only when this model confirms the mediation, we will test the other two model in which we take a closer look at (1) each of the four properties of agency to examine whether the methodical principles influence on or more property more than others and (2) each of the methodical principle to investigate whether a specific methodical principle is plays a more important role than others.

Model 1. Mediation of the Methodical principles on agency, through empowerment.

The first sets of models tested the indirect effects of the methodical principles altogether and of empowerment on agency (see Table 4). Results indicated that the methodical principles are a significant predictor of empowerment, and that empowerment is a significant predictor of agency. The methodical principles are also a significant predictor of agency. These results indicated that the indirect coefficient is significant, suggesting a partial mediation of the methodical principles 
The Girls Work Method: What is the Role of Empowerment in Building Girls' Agency?

on agency. In other words, the methodical principles contribute to girls' agency. This contribution is partially mediated by empowerment. However, this mediation only occurred when all three components were included.

The age of the girls and the duration of participation in Girls Work were inserted in the model as statistical controls on the dependent variable. Significant effects were found. Older girls were more likely to report a higher level of agency than younger girls $(\mathrm{B}=.13, \mathrm{SE}=.03, p=.001)$. Also, the duration of participation in Girls Work was positively associated $(\mathrm{B}=.05, \mathrm{SE}=.02, p=$ .009) with agency. However, these effects did not influence the mediation model, which indicate that both the age of girls and the duration of participation in Girls Work has no influence on the effects of the methodical principles on agency, through empowerment.

Table 4. Direct and indirect effects of the methodical principles on agency through empowerment

\begin{tabular}{|c|c|c|c|c|c|c|c|c|c|c|c|}
\hline \multirow{2}{*}{\multicolumn{2}{|c|}{$\mathrm{R} 2$}} & \multicolumn{2}{|l|}{ Path a } & \multicolumn{2}{|l|}{ Path b } & \multicolumn{2}{|l|}{ Path c } & \multicolumn{2}{|c|}{ Path c' } & \multirow[t]{2}{*}{$\mathrm{a} \times \mathrm{b}$} & \multirow[t]{2}{*}{$95 \% \mathrm{CI}$} \\
\hline & & B & SE & B & SE & B & SE & B & SE & & \\
\hline$X \rightarrow M \rightarrow Y$ & $.40 * * *$ & $.53 * * *$ & .04 & $.47 * * *$ & .05 & $.14 * * *$ & .04 & $.14 * *$ & .04 & .25 & $.19, .32^{\mathrm{a}}$ \\
\hline
\end{tabular}

Note. $\mathrm{CI}=$ Confidence interval.

$* * * p<.001 ; * * p<.01 ; * p<.05$

a Bias-corrected confidence interval does not overlap with zero

Model 2. Mediation of the methodical principles on each of the four properties of agency, through empowerment.

The second set of models tested whether the eight methodical principles influence each of the four properties of girls' agency individually, again through the mediation of empowerment. Results indicated that empowerment is a significant predictor of each of the properties of agency (see Table 5). The methodical principles are a significant predictor for two of the four properties of agency 
The Girls Work Method: What is the Role of Empowerment in Building Girls' Agency?

(forethought (Y2) and self-reflectiveness (Y4)). The methodical principles are not a significant predictor for the properties intentionality (Y1) and self-reactiveness (Y3). The results indicated that the indirect coefficient is significant for all properties of agency. This means that if we look at the four properties of agency individually, empowerment is a partial mediation of the methodical principles on forethought and self-reflectiveness. The influence of the methodical principles on the other two properties (intentionality and self-reactiveness) are fully mediated through empowerment.

Table 5. Direct and Indirect Effects of the Methodical Principles on the Properties of Agency

\begin{tabular}{|c|c|c|c|c|c|c|c|c|c|c|c|}
\hline \multirow[t]{2}{*}{ 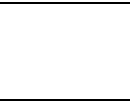 } & \multirow[t]{2}{*}{$\mathrm{R} 2$} & \multicolumn{2}{|l|}{ Path a } & \multicolumn{2}{|l|}{ Path b } & \multicolumn{2}{|l|}{ Path c } & \multicolumn{2}{|c|}{ Path c' } & \multirow[t]{2}{*}{$a \times b$} & \multirow[t]{2}{*}{$95 \% \mathrm{CI}$} \\
\hline & & B & SE & B & SE & B & SE & B & SE & & \\
\hline $\begin{array}{l}X \rightarrow M \\
\rightarrow Y 1\end{array}$ & $.29 * * *$ & $.53 * * *$ & .04 & $.40 * * *$ & .07 & $.35 * * *$ & .06 & .14 & .07 & .21 & $.12, .32^{\mathrm{a}}$ \\
\hline $\begin{array}{l}X \rightarrow M \\
\rightarrow Y 2\end{array}$ & $.15^{* * *}$ & & & $.36 * * *$ & .07 & $.34 * * *$ & .06 & $.15^{*}$ & .06 & .19 & $.11, .29^{a}$ \\
\hline $\begin{array}{l}X \rightarrow M \\
\rightarrow Y 3\end{array}$ & $.27 * * *$ & & & $.68 * * *$ & .07 & $.36^{* * *}$ & .06 & .00 & .07 & .36 & $.26, .48^{\mathrm{a}}$ \\
\hline $\begin{array}{l}X \rightarrow M \\
\rightarrow Y 4\end{array}$ & $.19 * * *$ & & & $.49 * * *$ & .09 & $.52 * * *$ & .07 & $.26^{* *}$ & .08 & .26 & $.15, .38^{\mathrm{a}}$ \\
\hline
\end{tabular}

Model 3. Mediation of each of the Methodical Principles on Agency, through empowerment..

The third set of models tested whether each of the eight methodical principles influence girls' agency as a whole, through the mediation of empowerment. All of the methodical principles proved to be significant predictors for empowerment (see Table 6). Five of the nine methodical principles are not a significant predictor for agency. However, we did find significant indirect effects of all the methodical principles and empowerment on agency. In other words, agency is fully mediated though empowerment by the methodical principles 'Acquaintance', 'Positive 
The Girls Work Method: What is the Role of Empowerment in Building Girls' Agency?

motivation', 'Expanding lifeworld', and 'Talking' (both individual and in groups). Agency is partially mediated through empowerment by the methodical principles 'Safety', 'Meaningful relationship', 'Take into account the needs of girls', and 'Boundaries'.

Table 6. Direct and Indirect Effects of the Nine Methodical Principles on Agency

\begin{tabular}{|c|c|c|c|c|c|c|c|c|c|c|c|}
\hline & \multirow[t]{2}{*}{$\mathrm{R} 2$} & \multicolumn{2}{|l|}{ Path a } & \multicolumn{2}{|l|}{ Path b } & \multicolumn{2}{|l|}{ Path c } & \multicolumn{2}{|l|}{ Path c' } & \multirow[t]{2}{*}{$a \times b$} & \multirow[t]{2}{*}{$95 \%$ CI } \\
\hline & & B & SE & B & SE & B & $\mathrm{SE}$ & B & SE & & \\
\hline $\begin{array}{l}\text { Safety }(X 1) \\
\rightarrow M \rightarrow Y\end{array}$ & $.39 * * *$ & $.09 * *$ & .03 & $.54 * * *$ & .04 & $.10 * * *$ & .02 & $.05^{*}$ & .02 & .05 & $.02, .09^{a}$ \\
\hline $\begin{array}{l}\text { Meaningful } \\
\text { relationship } \\
(X 2) \rightarrow M \rightarrow Y\end{array}$ & $.40 * * *$ & $.30 * * *$ & .03 & $.50 * * *$ & .04 & $.22 * * *$ & .03 & $.07 *$ & .03 & .15 & $.11, .20^{\mathrm{a}}$ \\
\hline $\begin{array}{l}\text { Acquaintance } \\
(X 3) \rightarrow M \rightarrow Y\end{array}$ & $.39 * * *$ & $.20 * * *$ & .03 & $.55 * * *$ & .04 & $.12 * * *$ & .03 & .01 & .03 & .11 & $.07, .15^{\mathrm{a}}$ \\
\hline $\begin{array}{l}\text { Take into } \\
\text { account the } \\
\text { needs of girls } \\
(X 4) \\
\rightarrow M \rightarrow Y\end{array}$ & $.40 * * *$ & $.28 * * *$ & .03 & $.49 * * *$ & .04 & $.22 * * *$ & .03 & $.08 * *$ & .03 & .14 & $.10, .18^{\mathrm{a}}$ \\
\hline $\begin{array}{l}\text { Positive } \\
\text { motivation } \\
(X 5) \rightarrow M \rightarrow Y\end{array}$ & $.39 * * *$ & $.40 * * *$ & .04 & $.522 * * *$ & .04 & $.26 * * *$ & .04 & .05 & .04 & .21 & $.16, .27^{\mathrm{a}}$ \\
\hline $\begin{array}{l}\text { Boundaries } \\
(X \sigma) \rightarrow M \rightarrow Y\end{array}$ & $.40 * * *$ & $.32 * * *$ & .03 & $.49 * * *$ & .04 & $.25 * * *$ & .03 & $.09 * *$ & .03 & .16 & $.11, .21^{\mathrm{a}}$ \\
\hline $\begin{array}{l}\text { Expanding } \\
\text { lifeworld }(X 7) \\
\rightarrow M \rightarrow Y\end{array}$ & $.39 * * *$ & $.13 * * *$ & .03 & $.54 * * *$ & .04 & $.10 * * *$ & .03 & .03 & .02 & .07 & $.04, .10^{\mathrm{a}}$ \\
\hline $\begin{array}{l}\text { Talk } \\
\text { individual }(X 8) \\
\rightarrow M \rightarrow Y\end{array}$ & $.38 * * *$ & $.08 * *$ & .03 & $.55 * * *$ & .04 & .06 & .03 & .01 & .02 & .05 & $.01, .08^{\mathrm{a}}$ \\
\hline $\begin{array}{l}\text { Talk in groups } \\
(X 9) \rightarrow M \rightarrow Y\end{array}$ & $.38 * * *$ & $.15^{* * *}$ & .03 & $.54 * * *$ & .04 & $.09 * * *$ & .03 & .01 & .02 & .08 & $.05, .12^{\mathrm{a}}$ \\
\hline
\end{tabular}

Note. $\mathrm{CI}=$ Confidence interval.

$* * * p<.001 ; * * p<.01 ; * p<.05$

${ }^{\text {a }}$ Bias-corrected confidence interval does not overlap with zero

\section{Discussion}

Youth workers state that Girls Work offers girls in vulnerable circumstances the opportunity to develop agency. This study has found a significant relationship between the methodical principles 
The Girls Work Method: What is the Role of Empowerment in Building Girls’ Agency?

of Girls Work and the level of agency of girls who participate in Girls Work. Eight methodical principles are positively related with agency, suggesting that what youth workers do in interaction with these girls indeed contributes to how girls manage to shape their own lives.

This study has furthermore yielded insight into the potential mechanisms underlying the contribution of the methodical principles to girls' agency. The present study supports an indirect effect model in which empowerment mediates the link between the methodical principles and agency. More specifically, the methodical principles of Girls Work contributes to the empowerment process of girls and young women. The empowerment process in turn contributes to the level of agency of girls. The findings confirm the importance of focusing on empowerment in professional Girls Work as a way to support the development of agency by girls and young women living in vulnerable circumstances. When focusing on the four properties of agency, we found that the girls' levels of intentionality and self-reactiveness are fully mediated by empowerment. The properties of forethought and self-reflection are partially mediated by empowerment, suggesting that the methodical principles also have a direct influence on these properties of agency. Could this be explained by the characteristics of the properties? While forethought and self-reflection involve contemplating actions and processes, the properties of intentionality and self-reactiveness focus on actually aiming for and doing what girls want in their lives, and may therefore require more power. To experience an intention and to actually do what they intend, girls need to believe in themselves, they need to develop a critical awareness, and they need to participate (be empowered)? Further research should focus on this question.

We found that five of the nine methodical principles are fully mediated by empowerment, which suggests that these principles contribute to how girls develop agency only indirectly. The methodical principles that contribute to agency indirectly are acquaintance, positive motivation, 
The Girls Work Method: What is the Role of Empowerment in Building Girls’ Agency?

expanding lifeworld and talk (both individual and in groups). This suggests that these principles are specific for supporting the empowerment process, which in turn is important for the development of agency. The other four methodical principles are partially mediated by empowerment. These principles - safety, meaningful relationship, take into account the needs of girls and boundaries - have a positive influence on both the empowerment process and the development of agency.

Despite the relationship between the girls' ages and their level of agency, the findings in this study are consistent for girls of all ages. This shows that, besides the development of agency associated with age, methodological principles of Girls Work can also play an important role. The duration of participation in Girls Work does not influence this mediation model.

In the literature on agency and empowerment, these two concepts are sometimes linked together (Christens et al., 2011; Donald et al., 2016; Lyons et al., 2001; Rich et al., 1995; Zimmerman et al., 1992). Some of these studies do not use Bandura's concept of agency or Rappaport's concept of empowerment, however. For instance, Donald et al. (2016) describes the link between personal control (first component of empowerment) and critical awareness (second component of empowerment) and agency, while Rich et al. (1995) focus on the link between participation and agency. In this study, we confirmed the relations between the components of empowerment and agency. However, it is hypothesized that to generate empowerment, all three components - personal control, critical awareness and participation - are necessary (Boomkens et al., 2018a). Our study findings confirm the importance of focusing on all three components to help girls shape their own lives, as the indirect effects only showed up when all three components were included in the model. 
The Girls Work Method: What is the Role of Empowerment in Building Girls’ Agency?

\section{Limitations of the study}

There are a number of limitations worth noting. First, respondents were asked whether they perceived the operation of the methodical principles in their Girls Work activity or youth worker. It is possible that respondents who did perceive the methodical principles are more self-conscious and therefore score higher on the level of agency.

Another limitation of this study is the cross-sectional design, which makes it difficult to infer causality. However, since both concepts are dynamic and subject to change, we wanted to explore how girls perceive their level of agency and empowerment at that point in time. Future research should focus on this effect using a longitudinal design.

Third, agency is defined as the ability of individuals to shape their own lives, in relation to their own values and in alignment with their own social context. In our operationalization, we did not ask the girls about the influence of their social context. Furthermore, because of an error in the software, we could not interrogate the girls about if and how their youth worker uses their social context to help them shape their own lives. Therefore, further research should focus on understanding how the social context of these girls influences their ability to shape their own lives.

Last, this study only focused on girls who participate in Girls Work activities in the Netherlands. Since the Netherlands is just one welfare state that offers professional youth work, it would be interesting to find out whether these findings also apply to professional Girls Work in other welfare states. It could be, however, that Girls Work is conceived and/or arranged differently in other countries.

\section{Conclusion}


The Girls Work Method: What is the Role of Empowerment in Building Girls' Agency?

This paper points out the importance for youth workers to focus on the empowerment of girls to help them develop their agency. The methodical principles of the Girls Work method contributes to the agency of girls in vulnerable circumstances. This contribution is mediated through empowerment. The study also confirms that to generate empowerment, all three components personal control, critical awareness and participation - are necessary.

We also found that at least eight of the nine methodical principles are important to helping girls shape their own lives. We found two groups of methodical principles, which contribute to agency in a different way. The first group contributes both directly to agency and indirectly through empowerment. These are safety, meaningful relationship, take into account the needs of girls and boundaries. The second group of methodical principles only contributes to agency indirectly through empowerment. These are acquaintance, positive motivation, expanding lifeworld and talking (both individual and in groups). The last methodical principle - use of social context could not be included in this study. Further research to determine how this methodical principle contributes to agency is required.

\section{Acknowledgements}

We would like express our special thanks of gratitude to Evelien Nijland-Rauwerdink, MSW, Jolanda Sonneveld, MSc., Dr. Willeke Manders, Fatima Bourri, M.Ed. and the students who assisted us in the data collection as part of their study. This research was funded by the Taskforce for Applied Research SIA, part of the Netherlands Organization for Scientific Research (NWO). The eight youth work providers who participated in this research also contributed financially to this research by permitting their youth workers to devote time to cooperating with our research. 
The Girls Work Method: What is the Role of Empowerment in Building Girls’ Agency?

This article is based on data that was also used in a previously report which is currently accepted for publication.

References:

Abdallah, S.E. (2017). Struggles for Success. Youth Work Rituals in Amsterdam and Beirut (Doctoral dissertation). University of Amsterdam, Amsterdam.

Akey, T.M., Marquis, J.G., \& Ross, M.E. (2000). Validation of scores on the Psychological Empowerment Scale: a measure of empowerment for parents of children with a disability. Educational and Psychological Measurement, 60(3), 419-438.

Doi:10.1177/00131640021970637

Alkire, S. (2005). Subjective quantitative studies of human agency. Social Indicators Research, 74, 217-260. Doi:10.1007/s11205-005-6525-0

Bandura, A. (2006). Toward a Psychology of Human Agency. Perspectives on Psychological Science, 1(2), 164-180. Doi:10.1111/j.1745-6916.2006.00011.x.

Batsleer, J. (2013). Youth working with girls and women in community settings: A feminist perspective. England: Ashgate Publishing Limited.

Baumans, J. (2012). Tussen regie en repressie. Een verkenning van het concept empowerment. [Between control and repression. An exploration of the concept of empowerment] Tijdschrift voor Rehabiltatie, 1, 28-42.

Berger, P.J., \& Neuhaus, R.J. (1977). To empower people: The Role of mediating structures in public policy. Washington, D.C.: American Enterprise Institute for Public Policy Research. 
The Girls Work Method: What is the Role of Empowerment in Building Girls' Agency?

Boomkens, C., \& Metz, J.W. (2015). Meidenwerk, hoe en waarom werkt het? Een theoretisch verklaringsmodel. [Girls work. How and why it works. Theoretical explanatory model]. Amsterdam (The Netherlands): Hogeschool van Amsterdam.

Boomkens, C., Nijland-Rauwerdink, E., Van der Grient., H., Van Trijp, C. \& Metz, J. (2018a). Kracht van meiden. Meidenwerk als specifieke methode van het jongerenwerk [Power of girls. Girls Work as a specific method of youth work]. Amsterdam (The Netherlands): SWP.

Boomkens, C., Metz, J.W., Van Regenmortel, M., \& Schalk, M.J.D. (2018b). The development of agency in professional girls work in the Netherlands. First published online June 2018. doi:10.1177/1468017318784079

Borovoy, A., \& Ghodsee, K. (2012). Decentering agency in feminist theory: Recuperating the family as a social project. Women's Studies International Forum, 35, 153-165. Doi:10.1016/j.wsif.2012.03.003.

Campbell, (2009). Distinguishing the Power of Agency from Agentic Power: A Note on Weber and the "Black Box" of Personal Agency. Sociological Theory 27(4), 407-418. Doi:10.1111/j.1467-9558.2009.01355.x

Charrad, M.M. (2010). Women’s agency across cultures: Conceptualizing strengths and boundaries. Women's Studies International Forum, 33, 517-522.

Doi:10.1016/j.wsif.2010.09.004.

Christens, B.D., Peterson, N.A., \& Speer, P.W. (2011). Community participation and psychological empowerment: Testing reciprocal causality using a cross-lagged panel design and latent constructs. Health Education \& Behavior, 38(4), 339-347. doi: $10.1177 / 1090198110372880$. 
The Girls Work Method: What is the Role of Empowerment in Building Girls' Agency?

De Boer, E.E., \& Metz, J.W. (2014). Meiden? Dit kan je ermee. Methodische principes van het sekse specifiek werken met meiden. [This is what you can do with girls! Methodic principles of girls work]. Amsterdam (The Netherlands): Hogeschool van Amsterdam.

Delahaij, R. (2004). Dossier empowerment. Empowerment methoden bij allochtone jongeren. [Empowerment File. Empowerment Methods for immigrant youth] Utrecht (The Netherlands): FORUM, Instituut voor multiculturele ontwikkeling.

Donald, A., Koolwal, G., Annan, J., Falb, K., \& Goldstein, M. (2017). Measuring women’s agency. World Bank Policy Research Working Paper No. 8148, 2017. Retrieved from http://documents.worldbank.org/curated/en/333481500385677886/Measuring-womensagency.

Drydyk, J. (2013). Empowerment, agency and power. Journal of global ethics, 9(3), 249-262. Doi:10.1080/17449626.2013.818374

Dunne, A. Ulicna, D. Murphy, I. \& Golubeva, M. (2014). Working with young people: the value of youth work in the European Union. Brussels (Belgium): European Commission.

Elder, G.H. (1998). The Life Course as Developmental Theory. Child Development, 69(1), 1-12. Doi:10.2307/1132065

Field, A. (2009). Discovering Statistics using SPSS. Londen: Sage.

Gemmeke, M., Hilverdonk, P., Hoogenes, A., Valkestijn, M., Vink, C., \& Smid, M. (2011). Emancipatie van het jongerenwerk. [Emancipation of youth work]. Utrecht (The Netherlands): Nederlands Jeugdinstituut. Retrieved from https://www.nji.n1/n1/DownloadNJi/Publicatie-NJi/Emancipatie jongerenwerk.pdf.

Gillespie, A. (2012). Position exchange: The social development of agency. New Ideas in Psychology, 30, 32-46. Doi:10.1016/j.newideapsych.2010.03.004 
The Girls Work Method: What is the Role of Empowerment in Building Girls’ Agency?

Haidinger, B., Kasper, R., Knecht, A., Kuchler, K., \& Atzmüller, R. (2016). Youth Policies and Gender-sensitive Youth Work in Austria. Evidence from a Capability-oriented Perspective. A Compilation of National Case Study Reports from the EU-project SocIEtY, FORBA Research Report 1/2016. Retrieved from http://www.forba.at/data/downloads /file/1145-FB_01_2016.pdf.

Han, H., Nicholas, A., Aimer, M., \& Gray, J. (2015). An innovative community organizing campaign to improve mental health and wellbeing among Pacific Island youth in South Auckland, New Zealand. Australian Psychiatry, 23(6), 670-674.

Doi: $10.1177 / 1039856215597539$

Hutchison, E. (2005). The life course perspective: A promising approach for bridging the micro and macro worlds for social work. Families in Society: The Journal of Contemporary Social Services, 86(1), 143-152. Retrieved from http://alliance1.metapress.com/index/ 85TX3Q0674P17277.pdf

Israel, B., Checkoway, B., Schulz, A., \& Zimmerman, M (1994). Health Education and Community Empowerment: Conceptualizing and Measuring Perceptions of Individual, Organizational, and Community Control. Health Education \& Behavior 21(2): 149-170. doi: $10.1177 / 109019819402100203$.

Lyons, M., Smuts, C., \& Stephens, A. (2001). Participation, empowerment and sustainability: (How) Do the links work? Urban Studies, 38(8), 1233-1251. doi:10.1080/00420980125039.

Maynard, L. \& Stuart, K. (2018). Promoting young people's wellbeing though empowerment and agency. A critical framework for practice. New York: Routledge. 
The Girls Work Method: What is the Role of Empowerment in Building Girls’ Agency?

McMunn, A., Bartley, M., \& Kuh, D. (2006). Women's health in mid-life: Life course social roles and agency as quality. Social Science \& Medicine, 63, 1561-1572. Doi: 10.1016/j.socscimed.2006.03.039.

Meesters, J. (2018). Ruimte voor opgroeien. Jongeren en het belang van de informele wereld. [Room for growing up. Youth and the significance of the informal world]. (Doctoral dissertation). University of Humanistic Studies, Utrecht.

Metz, J.W. (2016). De ontwikkeling van een met onderzoek onderbouwde methodiek voor het meidenwerk. [The development of a method substantiated by research for girls work]. Journal of Social Intervention: Theory and Practice. 25(1), pp.47-70. Doi:10.18352/jsi.431.

Paternoster, R. \& Pogarsky, G. (2009). Rational Choice, Agency and Thoughtfully Reflective Decision Making: The Short and Long-Term Consequences of Making Good Choices. J Quant Criminol, 25:103-127. Doi:10.1007/s10940-009-9065-y.

Philips, A. (2013) Does the body make a difference? In S. Madhok, A. Phillips, \& K. Wilson (Eds.), Gender, Agency, and Coercion. Thinking gender in transnational times (pp. $143-$ 156). Londen: Palgrave macmillan.

Pollack, S. (2000). Reconceptualizing Women's Agency and Empowerment. Women \& Criminal Justice, 12(1), 75-89. doi:10.1300/J012v12n01_05.

Preacher, K. J., \& Hayes, A. F. (2008). Asymptotic and resampling strategies for assessing and comparing indirect effects in multiple mediator models. Behavior Research Methods, 40, 879-891. doi:10.3758/BRM.40.3.879. 
The Girls Work Method: What is the Role of Empowerment in Building Girls' Agency?

Prestby, J., Wandersman, A., Florin, P., Rich R., \& Chavis, D. M. (1990). Benefits, costs, incentives management and participation in voluntary associations. American Journal of Community Psychology, 18, 117-149. doi:10.1007/BF00922691.

Rappaport, J. (1987). Terms of empowerment/exemplars of prevention: Towards a theory for community psychology. American Journal of Community Psychology, 15(2), 121-148. Doi:10.1007/BF00919275.

Rossi, P. H., Lipsey, M. W., \& Freeman, H. E. (2004). Evaluation. A systematic approach (7th ed.). Thousand Oaks, London and New Delhi: Sage.

Rich, R.C., Edelstein, M., Hallman, W.K., \& Wandersman, A.H. (1995). Citizen Participation and Empowerment: The Case of Local Environmental Hazards. American Journal of Community Psycology, 23(5), 657-676. doi:10.1007/BF02506986.

Samman, E., \& Santos, M.E. (2009). Agency and Empowerment: A review of concepts, indicators and empirical evidence. Retrieved from http://www.ophi.org.uk/wpcontent/uploads/OPHI-RP-10a.pdf.

Swartz, S.J., Cote, J.E., \& Arnett, J.J. (2005). Identity and Agency in Emerging Adulthood: Two Developmental Routes in the Individualization Process, Youth Society, 37(2), 201-229. doi:10.1177/0044118X05275965

Stuart, K. (2014). Collaborative agency to support integrated care for children, young people and families: an action research study. International Journal of Integrated Care, 14, 1-13. doi:10.5334/ijic. 1171

Tang, S.Y.S., \& Anderson, J.M. (1999). Human agency and the process of healing: lessons learned from women living with a chronic illness - 're-writing the expert'. Nursing Inquiry, 6, 8393. doi:10.1046/j.1440-1800.1999.00022.x. 
The Girls Work Method: What is the Role of Empowerment in Building Girls' Agency?

Teeuw, B., Schwarzer, R., \& Jerusalem, M. (1994). Dutch Adaptation of the General SelfEfficacy Scale. Berlin. Retrieved from http://userpage.fu-berlin.de/ health/dutch.htm

Van der Zande, I. (1991) Het is meisjes menens, inleiding meisjesstudies [Girls are serious, introduction to girls' studies]. Amersfoort (The Netherlands): Acco.

Van Drenth, A., \& te Poel, Y. (1991). Van meisjesclub tot meidencafé [From girls club to girls café]. In I van der Zande (Ed.), Het is meisjes menens, inleiding meisjesstudies (pp. 81-95). Amersfoort (The Netherlands): Acco.

VSNU. (2014). The Netherlands Code of Conduct for Academic Practice. Principles of good academic teaching and research. The Hague, The Netherlands: Association of Universities in the Netherlands (VSNU). Retrieved from http://www.vsnu.nl/files/documenten/ Domeinen/Onderzoek/The_Netherlands_Code\%20of_Conduct_for_Academic_Practice_ 2004_(version2014).pdf.

Zimmerman, M.A. (1995). Psychological empowerment: Issues and illustrations. American Journal of Community Psychology, 23(5), 581-599. doi:10.1007/BF02506983.

Zimmerman, M.A., Israel, B.A., Schulz, A., \& Checkoway, B. (1992). Further explorations in empowerment theory: An empirical analysis of psychological empowerment. American Journal of Community Psychology, 20, 707-727. doi:10.1007/BF01312604. 
The Girls Work Method: What is the Role of Empowerment in Building Girls' Agency?

\section{Appendix}

Girls Work Empowerment Scale (original in Dutch).

We have developed this scale to measure empowerment within girls between 10 and 23 years, who participate in professional Girls Work in the Netherlands.

\begin{tabular}{|c|c|c|c|c|c|}
\hline & 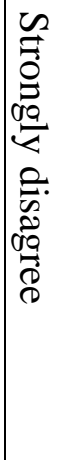 & 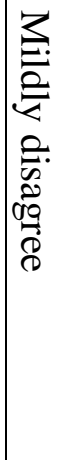 & 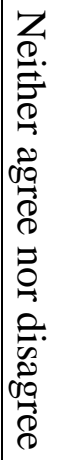 & 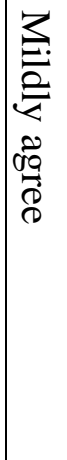 & 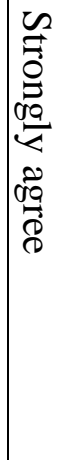 \\
\hline \multicolumn{6}{|l|}{ Personal Control } \\
\hline \multicolumn{6}{|l|}{ I believe in myself } \\
\hline \multicolumn{6}{|l|}{ I believe that I have the power to change something in a positive way } \\
\hline \multicolumn{6}{|l|}{ I believe that I can achieve everything that I want } \\
\hline \multicolumn{6}{|l|}{ When I fail to achieve something, that is mostly someone else's fault } \\
\hline \multicolumn{6}{|l|}{ I am motivated to do whatever I think is important / to be myself } \\
\hline \multicolumn{6}{|l|}{ I am motivated to handle situations that I want to change } \\
\hline \multicolumn{6}{|l|}{ I am motivated to work on my future } \\
\hline \multicolumn{6}{|l|}{ Critical Awareness } \\
\hline \multicolumn{6}{|l|}{$\begin{array}{l}\text { I am searching for possibilities in my own context to work on things I want to } \\
\text { achieve }\end{array}$} \\
\hline \multicolumn{6}{|l|}{$\begin{array}{l}\text { I am searching for new possibilities in new contexts to work on something I } \\
\text { want to achieve }\end{array}$} \\
\hline \multicolumn{6}{|l|}{ I am searching for new information that I need to achieve what I want } \\
\hline \multicolumn{6}{|l|}{ I know who can ask for help, when I want to do/achieve something } \\
\hline \multicolumn{6}{|l|}{ I am learning new skills, so i can do/achieve what I want } \\
\hline \multicolumn{6}{|l|}{ I become aware of the skills that I already possess } \\
\hline \multicolumn{6}{|l|}{ Participation } \\
\hline I am practicing what I want to do/achieve in the Girls Work activity & & & & & \\
\hline I am practicing what I want to do/achieve outside of the Girls Work activity & & & & & \\
\hline
\end{tabular}


The Girls Work Method: What is the Role of Empowerment in Building Girls' Agency?

\begin{tabular}{|l|l|l|l|l|}
\hline $\begin{array}{l}\text { Within the Girls Work activity, I am actually working on what I want to } \\
\text { do/achieve }\end{array}$ & & & & \\
\hline $\begin{array}{l}\text { Outside of the Girls Work activity, I am actually working on what I want to } \\
\text { do/achieve }\end{array}$ & & & & \\
\hline
\end{tabular}

Perceived Methodical Principles of Girls Work (original in Dutch).

We have developed this scale to measure whether girls between 10 and 23 years, who participate in professional Girls Work in the Netherlands, recognize the methodical principles of Girls Work.

\begin{tabular}{|c|c|}
\hline & Scale \\
\hline \multicolumn{2}{|l|}{ Safety } \\
\hline I feel safe when I participate in the Girls Work activity & 4 point Likert-scale \\
\hline \multicolumn{2}{|l|}{ Meaningful relationship } \\
\hline I think the youth worker trusts me & 5 point Likert-scale \\
\hline I trust the youth worker & 5 point Likert-scale \\
\hline $\begin{array}{l}\text { I take seriously what the youth worker says to me, even if I'm not happy about } \\
\text { it }\end{array}$ & 5 point Likert-scale \\
\hline My youth worker understands me & 5 point Likert-scale \\
\hline \multicolumn{2}{|l|}{ Acquaintance } \\
\hline My youth worker knows my personal situation & 5 point Likert-scale \\
\hline My youth worker knows what I am good at (my talents) & 5 point Likert-scale \\
\hline My youth worker knows what I am less good at & 5 point Likert-scale \\
\hline My youth worker knows what I need / what suits me & 5 point Likert-scale \\
\hline \multicolumn{2}{|l|}{ Take into account the needs of girls } \\
\hline For me, the Girls Work activity is a place where I find what I need & 5 point Likert-scale \\
\hline $\begin{array}{l}\text { For me, the Girls Work activity is a place where I can work on my (personal) } \\
\text { goals }\end{array}$ & 5 point Likert-scale \\
\hline \multicolumn{2}{|l|}{ Positive motivation } \\
\hline $\begin{array}{l}\text { During the Girls Work activity there is (positive) attention for who I am, what I } \\
\text { can do or what I do }\end{array}$ & 4 point Likert-scale \\
\hline
\end{tabular}


The Girls Work Method: What is the Role of Empowerment in Building Girls' Agency?

\begin{tabular}{|c|c|}
\hline $\begin{array}{l}\text { Indicate how much attention the following people have for you: } \\
\text { - } \text { My youth worker } \\
\text { - } \text { Other girls in the Girls Work activity } \\
\text { - } \text { Others, such as volunteers }\end{array}$ & $\begin{array}{l}5 \text { point Likert-scale } \\
\text { (with an option 'does } \\
\text { not apply') }\end{array}$ \\
\hline $\begin{array}{l}\text { My youth worker appreciates what I do or what I can do (gives compliments, } \\
\text { for example) }\end{array}$ & 5 point Likert-scale \\
\hline My youth worker appreciates what we do or can do as a group (perform) & 5 point Likert-scale \\
\hline \multicolumn{2}{|l|}{ Boundaries } \\
\hline $\begin{array}{l}\text { Because of the rules drawn up in the Girls Work activity, it is clear how we } \\
\text { deal with each other }\end{array}$ & 5 point Likert-scale \\
\hline $\begin{array}{l}\text { Because of the rules drawn up in the Girls Work activity, I learn to better } \\
\text { understand the world around me }\end{array}$ & 5 point Likert-scale \\
\hline $\begin{array}{l}\text { Because of the rules drawn up in the Girls Work activity, I manage to } \\
\text { participate }\end{array}$ & 5 point Likert-scale \\
\hline My youth worker encourages me to indicate what I like and what I do not like? & 5 point Likert-scale \\
\hline $\begin{array}{l}\text { Because my youth worker encourages me to indicate my own limits I manage } \\
\text { to better indicate what I like and do not like }\end{array}$ & 5 point Likert-scale \\
\hline $\begin{array}{l}\text { Because my youth worker encourages me to indicate my own limits I also } \\
\text { manage to indicate in other places what I like and dislike }\end{array}$ & 5 point Likert-scale \\
\hline $\begin{array}{l}\text { Because my youth worker encourages me to indicate my own limits, I take into } \\
\text { account what others do and do not like }\end{array}$ & 5 point Likert-scale \\
\hline $\begin{array}{l}\text { Because my youth worker encourages me to indicate my own limits, I learn } \\
\text { that I can do something myself }\end{array}$ & 5 point Likert-scale \\
\hline $\begin{array}{l}\text { Because my youth worker encourages me to indicate my own limits, I believe } \\
\text { (more) in myself }\end{array}$ & 5 point Likert-scale \\
\hline \multicolumn{2}{|l|}{ Expanding lifeworld } \\
\hline $\begin{array}{l}\text { Do you become acquainted with new environments (such as new places, new } \\
\text { people or new agencies) through your youth worker? }\end{array}$ & 4 point Likert-scale \\
\hline \multicolumn{2}{|l|}{ Talk } \\
\hline $\begin{array}{l}\text { Do you have individual conversations (1-on-1) with your youth worker? } \\
\text { (talking individual) }\end{array}$ & 4 point Likert-scale \\
\hline $\begin{array}{l}\text { Do you take part in group discussions during the Girls Work activity (with } \\
\text { other girls)? (Talking in group) }\end{array}$ & 4 point Likert-scale \\
\hline
\end{tabular}


The Girls Work Method: What is the Role of Empowerment in Building Girls’ Agency?

Items were measured on either a 4 point Likert-scale or a 5 point Likert-scale:

4 point Likert-scale: $1=$ never; $2=$ sometimes; $3=$ often; $4=$ always

5 point Likert-scale: $1=$ strongly disagree; $2=$ disagree; $3=$ Neither agree nor disagree; $4=$ agree; $5=$ strongle agree. 